\title{
Study of the toxicity of ethanolic extract of Schrankia leptocarpa D.C in the treatment of dental caries in Côte d'Ivoire
}

\author{
Marie Rosine ATSAIN-ALLANGBA ${ }^{1 *}$, Edgard Valery ADJOGOUA ${ }^{2}$, Eugène KOFFI ${ }^{3}$, \\ Amani Brice KADJA ${ }^{1}$, Aya Nathalie KOUADIO-GUESSENND ${ }^{4}$, Janat Akhanovna \\ MAMYRBEKOVA-BÉKRO ${ }^{1}$ and Yves-Alain BÉKRO ${ }^{1}$
}

\author{
${ }^{1}$ Université Nangui Abrogoua, Laboratoire de Chimie Bio-Organique et de Substances Naturelles / UFR-SFA / \\ Université Nangui Abrogoua, 02 BP 801 Abidjan 02, Côte d'Ivoire. \\ ${ }^{2}$ Institut Pasteur de Cote d'Ivoire, Département des Virus Épidémiques, 01 BP 490 Abidjan 01, Côte d'Ivoire. \\ ${ }^{3}$ Institut Pasteur de Cote d'Ivoire, Unité des Gestions des Ressources Animales, 01 BP 490 Abidjan 01, \\ Côte d'Ivoire. \\ ${ }^{4}$ Université Félix Houphouët Boigny, UFR de Sciences Médicales, Unité de Surveillance de la Résistance des \\ Micro-organismes aux Anti-Infectieux (ASSURMI), Département de Bactériologie Virologie de l'Institut \\ Pasteur, 01 BP 490 Abidjan 01, Côte d'Ivoire. \\ *Corresponding author; E-mail : atsainmarierosine@yahoo.fr; Tel : (225) 0707367881.
}

\begin{abstract}
\begin{tabular}{lll}
\hline Received: 18-06-2021 & Accepted: 15-10-2021 & Published: 30-10-2021 \\
\hline
\end{tabular}
ABSTRACT

Schrankia leptocarpa (S. leptocarpa) is a plant found in the Mimosaceae family. It is used in the treatment of dental caries in Côte d'Ivoire. Because of the direct contact of the decoction with the cells of the mouth and the risk of swallowing it, we have been interested in the study of the toxicity of S. leptocarpa. The aim of our study was to assess the risks linked to the toxicity of plant during the traditional treatments. To achieve this goal, cytotoxicity and acute oral toxicity tests of the ethanolic extract of $S$. leptocarpa $(\mathrm{P})$ were carried out at different concentrations on Vero $E_{6}$ cells from the black monkey kidneys of West Africa and on Swiss mice. This study showed a cytotoxic effect of extract $\mathrm{P}$ on Vero $\mathrm{E}_{6}$ cells for all the concentrations ranged from 10 to $2.5 \mu \mathrm{g} / \mathrm{mL}$ from the second day. This extract has been found to be no-toxic with an $\mathrm{LD}_{50}$ greater than $5000 \mathrm{mg} / \mathrm{kg}$. At the end of this study, it was shown that $S$. leptocarpa could be used in the treatment of dental caries without any fear of toxicity.
\end{abstract}

(C) 2021 International Formulae Group. All rights reserved.

Keywords: Cytotoxicity, acute toxicity, Vero E6, Swiss mice, LD50.

\section{INTRODUCTION}

For socio-cultural and economic reasons, a large part of the African population uses medicinal plants (OMS, 2001). The therapeutic use, accidental ingestion or the confusion of these plants with other edibles, are the main causes of frequent accidents in the world (Fourasté, 2000). Thankfully, the use of medicinal plants has been especial and widely spreaded in the treatment of dental caries (Bayeli et al., 2019). Tooth decay is a microbial condition that is manifested as a progressive 
destruction of the hard tooth tissue (Vidal, 2019). It is ranked as the third plague in the world's (Galmiche, 2011), and affects more than 60 to $90 \%$ of students and almost $100 \%$ of adults (OMS, 2012). After the results of ethnobotanical surveys carried out in the regions of Mé and Bélier, located respectively in the south and in the center of the Ivory Coast, our choice fell on Schrankia leptocarpa DC., A Leguminosae-Mimosoideae for this study. This plant is traditionally used as a mouthwash in the treatment of tooth decay (Atsain, 2017). The antibacterial tests of the aqueous and hydroethanolic extracts of $S$. leptocarpa carried out showed that the ethanolic extract $\mathrm{P}$ had better activity with respect to the bacterial strains of Streptococcus mutans. In addition, this extract has shown very good analgesic activity (Atsain, 2017). To recommend the traditional use of $S$. leptocarpa, cytotoxicity and acute oral toxicity were evaluated.

\section{MATERIALS AND METHODS \\ Plant material}

For our study, the whole plant of $S$. leptocarpa was used as the plant material. It was harvested in 2014 in the south of Côte d'Ivoire in the Mé region, more precisely in Abié and identified at the National Floristic Center (CNF) in Abidjan (Côte d'Ivoire) under the number UCJ009858. The plant material was then dried under permanent air conditioning $\left(18^{\circ} \mathrm{C}\right)$ for a week, then reduced into a fine powder using a grinder (Laboratory Blender( $($ ) at the Laboratory of Bio-Organic Chemistry and Natural Substances of Nangui Abrogoua University. The powder was then sampled for the different analyzes.

\section{Animal model used in the experiment}

The experimental animal model was extracted from Vero $E_{6}$ cells; originally extracted from the kidney of the black monkey; this model was used to evaluate the cytotoxicity of our extracts. Moreover, the female Swiss albino mice aged about 4 to 6 weeks, healthy, of weights between 19 and 27 $\mathrm{g}$, from the Pro 5 animal facility at Félix Houphouët-Boigny University in Cocody (Abidjan / Côte d'Ivoire), were used to carry out the test for the acute oral toxicity of the extract. The animals were treated in accordance with the recommendations of bioethics (OCDE, 2001a).

\section{Extract preparation}

The extraction was carried out according to the method used by GuessenndKouadio et al. (2013). $200 \mathrm{~g}$ of the powder were introduced into an Erlenmeyer flask topped with a condenser, $1 \mathrm{~L}$ of ethanol $(96 \%)$ was added to the flask and the whole was brought to a reflux boiling for $30 \mathrm{~min}$ on a sand bath. After cooling, the decocted was filtered. The filtrate was concentrated at $60{ }^{\circ} \mathrm{C}$ under vacuum using a rotary evaporator and dried out in an oven for 3 days at $50^{\circ} \mathrm{C}$ to obtain the total ethanolic extract $\mathrm{P}$, which under tight protection was kept in the refrigerator at $4{ }^{\circ} \mathrm{C}$.

\section{Study of cytotoxic activity Cell viability test}

For this test, a slight modification of the Musa et al. (2014) method was used. For this test, a concentration of $0.41 \mathrm{mg} / \mathrm{mL}$ was prepared for the extract in 10\% MEM medium (Minimum Essential Environment). Vero E6 cells grown in $75 \mathrm{~cm}^{2}$ culture dishes were individualized from trypsinethylenediaminetetraacetic (EDTA) $(0.025 \%$ trypsin, $0.01 \%$ EDTA) (25300-054). A number of $0.5 \times 10^{5}$ cells $/ \mathrm{mL}$ was cultured in $2 \mathrm{~mL}$ of MEM growth at $10 \%$ in 11 culture tubes of 2 $\mathrm{cm}^{2}$ and incubated for $48 \mathrm{~h}$ at $37^{\circ} \mathrm{C}$, under $5 \%$ of $\mathrm{CO}_{2}$. Before the test, a tube was trypsinized in order to know the exact number of cells $\left(0.63 \times 10^{6}\right.$ cells $/ \mathrm{mL}$ in the different tubes). 2 $\mathrm{mL}$ of growth medium (10\% Fetal Calf Serum: FCS) and $50 \mu \mathrm{L}$ of the extract were added to the tubes containing the cell mats, except for the controls, then returned to the oven at $37^{\circ} \mathrm{C}$, under $5 \%$ of $\mathrm{CO}_{2}$. Which gives us an extract concentration equal to $10 \mu \mathrm{g} / \mathrm{mL}$. A daily reading of an experimental tube and a control 
tube using an inverted microscope was taken every morning for 5 days.

\section{Cell sensitivity test}

The method used is a slight modification of that carried out by Ambe et al. in 2016. A range of extract concentrations from $20 \mu \mathrm{g} / \mathrm{mL}$ to $0.039 \mu \mathrm{g} / \mathrm{mL}$ were prepared using the double dilution method. The Vero $\mathrm{E}_{6}$ cell carpet contained in a $75 \mathrm{~cm}^{2}$ culture dish was trypsinized and a suspension of $3.6 \times 10^{6}$ cells $/ \mathrm{mL}$ was produced. The Vero E6 cell layer contained in a $75 \mathrm{~cm}^{2}$ culture dish was trypsinized and a suspension of $3.6 \times 106$ cells $/ \mathrm{mL}$ was produced. The different concentrations were distributed in the wells of a microplate wells of a 96-well microplate, at a rate of $100 \mu \mathrm{L}$ of an extract concentration per well. Then a quantity of $100 \mu \mathrm{L}$ of the cell suspension was in the wells. The control consists of cell suspension only. A number of 10 test wells and a control well constituted one test. This operation was repeated 3 times on the plate. A total of 5 plates were used. The different microplates were incubated at $37{ }^{\circ} \mathrm{C}$ in a $5 \% \mathrm{CO}_{2}$ atmosphere. The daily reading of a plate was carried out for 5 days using an inverted microscope in order to observe the effect of the extract on the cells. At the end of the readings, the reaction medium and the microplates were rinsed with a phosphatebuffered saline (PBS) solution. $100 \mu \mathrm{L}$ of violet crystal dye were placed in the microplates and left for 24 hours on the bench. Then, the dye was aspirated and the microplates were rinsed with distilled water. The presence of plaque and the extent of their surface area, reflected by the absence of blue coloration in the wells, demonstrates the cytotoxic effect of the different concentrations of the extracts.

\section{Assessment of the acute toxicity of $S$. leptocarpa \\ Experimental protocol}

For the study of toxicity, the method 423 according to OECD (OCDE, 2001b) was carried out. At each stage of the test, 3 mice were used. These mice were females and were fed only with water for 3 to 4 hours before the test. As we did not have any information on the extracts to be tested, an initial concentration of $300 \mathrm{mg} / \mathrm{kg}$ of BW was administered to the animals by oral route an initial concentration of $300 \mathrm{mg} / \mathrm{kg}$ of $\mathrm{BW}$ was administered to the animals orally at a rate of $100 \mathrm{~mL}$ per $100 \mathrm{~g}$ of BW. None observed no deaths, the dose of $2000 \mathrm{mg} / \mathrm{kg}$ of body mass was administered. Two hours after the administration of the extracts, the mice were observed $30 \mathrm{~min}, 4 \mathrm{~h}$, $24 \mathrm{~h}$ and daily for 14 days. Signs of toxicity observed in animals have been registered.

\section{Statistical analysis of the results}

The comparison of the results between the control and the tests was made using the ANOVA variance, followed by the Tukey test. The kruskal Wallis, Freidman tests and excel logicial were also used. The results obtained were expressed as an average \pm standard deviation. $\mathrm{P}<0.05$ was considered statistically significant, and $\mathrm{P}<0.01$, very significant.

\section{RESULTS}

\section{Yield of the extractions}

For $200 \mathrm{~g}$ of organs removed, the ethanolic decoction of the whole plant has an extraction yield equal to $10.77 \%$. This extract has a low yield compared to that of $T$. glaucescens $(14.8 \mathrm{~g})$ obtained from $100 \mathrm{~g}$ of organ (Konan et al., 2016).

\section{Cytotoxicity studies}

\section{Measurement of cytotoxicity}

The percentages of viability of Vero $\mathrm{E}_{6}$ cells after the treatment for 24 to $120 \mathrm{~h}$ with 10 $\mu \mathrm{g} / \mathrm{ml}$ of extract are presented in Figure 1. We observe that after 24 hours of presence of ethaolic extract $\mathrm{P}$ in the culture medium, no influence on the viability of the cells was observed. On the other hand, from the 2nd day to the 5th day, $\mathrm{P}$ causes a decrease in the viability percentage of between 0 and 20 .

Figure 2 shows the shape of cells during the experimentation. The observed granule 
shape in (Figure 2 B) is caused by toxic effect of $\mathrm{P}$ extract. Figure $2 \mathrm{~A}$ shows Véro $\mathrm{E}_{6}$ normals cells shape.

\section{Sensitivity of cells}

The sensitivity test was performed following a modification of that used by IrieN'guessan et al. in 2011. This sensitivity test, based on the presence or absence of blue coloration in the wells of the experimental microplates, confirms the tests previously carried out. It was observed an increase in the toxicity of the extract over time and in a straight correlation with the concentrations used. Extract $\mathrm{P}$ showed a cytotoxic effect up to $2.5 \mu \mathrm{g} / \mathrm{mL}$ (Table 1).

\section{Acute oral toxicity \\ Toxic effects}

The behavior of all the experimental mice after oral gavage with the crude extract at 300 and $2000 \mathrm{mg} / \mathrm{kg}$ of body weight (BW) for $30 \mathrm{~min}$ is recorded in Table 2. After $4 \mathrm{~h}, 1$ day until the 14th day, no signs and deaths were observed (Table 2).

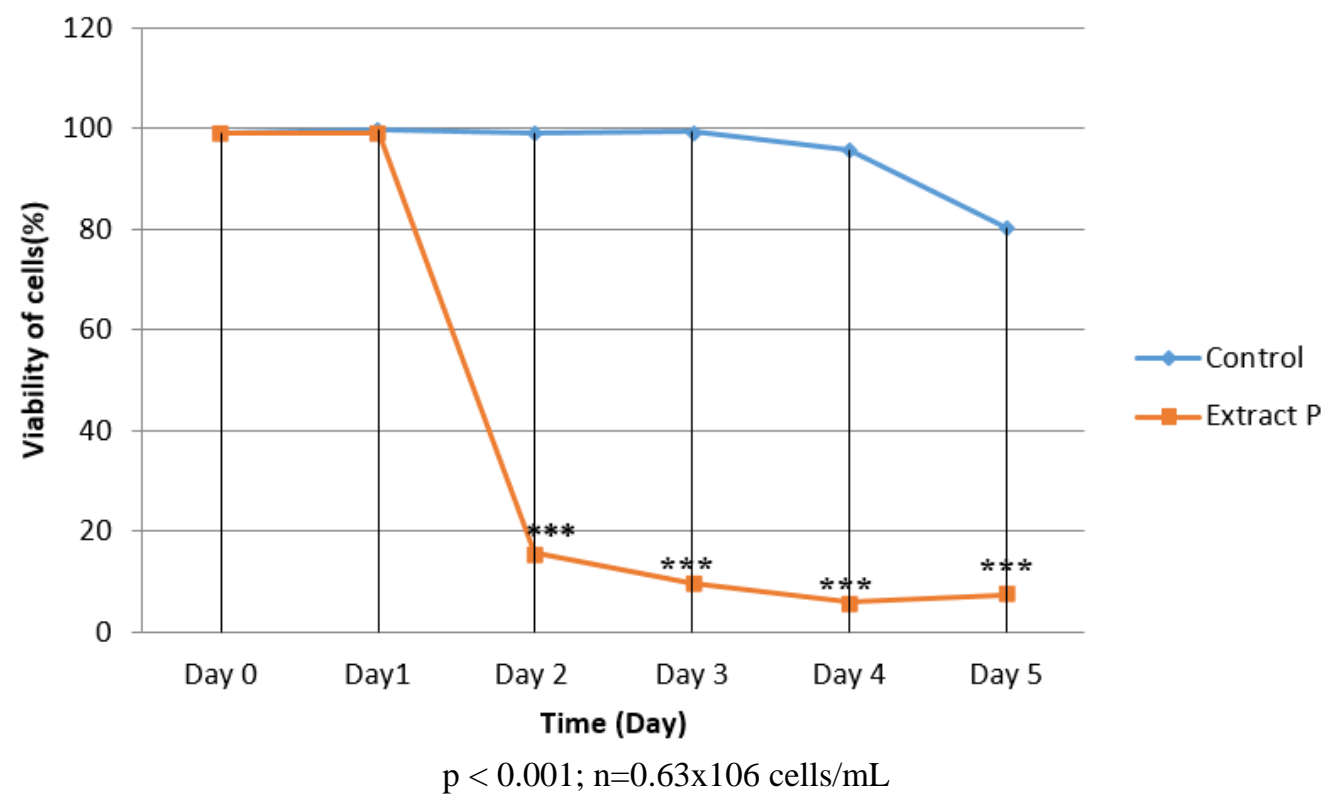

Figure 1: Viability of Vero $\mathrm{E}_{6}$ cells.
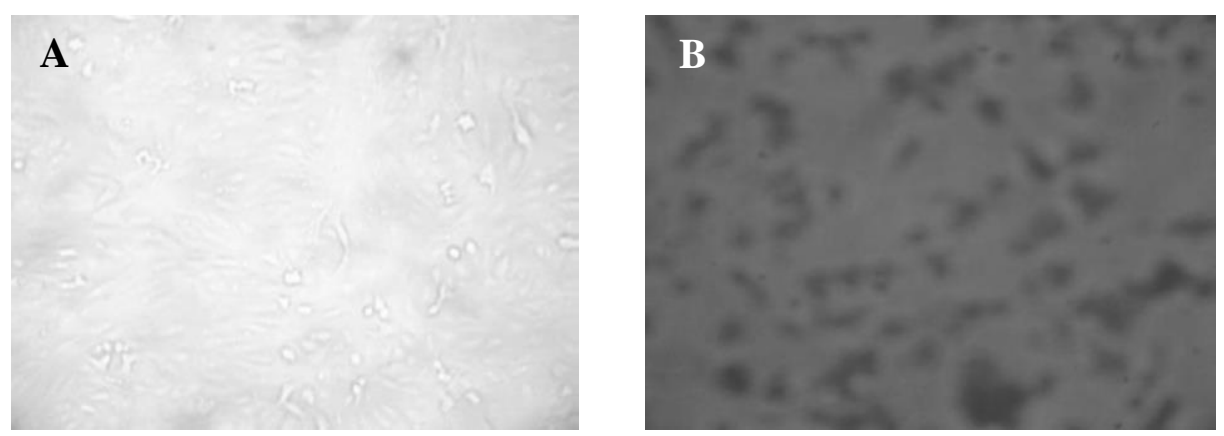

Figure 2: Véro E6 Cells before (A) and after experimentation (B). 
Table 1: Sensitivity of Vero $\mathrm{E}_{6}$ cells to the extracts as a function of time.

\section{Concentration of extracts $(\mu \mathrm{g} / \mathrm{mL})$}

\begin{tabular}{llllllllllllll}
\hline $\begin{array}{l}\text { Days and } \\
\text { substances }\end{array}$ & 10 & 5 & 2.5 & 1.25 & 0.625 & 0.312 & 0.156 & 0.078 & 0.039 & 0.0195 & 0 \\
\hline $\mathbf{D 1}$ & $\mathbf{P}$ & \pm & \pm & - & - & - & - & - & - & - & - & - \\
\hline $\mathbf{D 2}$ & $\mathbf{P}$ & + & + & + & - & - & - & - & - & - & - & - \\
\hline $\mathbf{D 3}$ & $\mathbf{P}$ & + & + & + & - & - & - & - & - & - & - & - \\
\hline $\mathbf{D 4}$ & $\mathbf{P}$ & + & + & + & - & - & - & - & - & - & - & - \\
\hline $\mathbf{D 5}$ & $\mathbf{P}$ & + & + & + & - & - & - & - & - & - & - & - \\
\hline
\end{tabular}

$\pm:$ Appearance of cytotoxic effect; +: presence of cytotoxic effect; -: Absence of toxic effect.

Table 2: Signs of toxicity.

\begin{tabular}{lll}
\hline Extract & Concentration (mg/kg B.M.) & Observations \\
\hline & 300 & $\begin{array}{l}\text { Tremor, sleep, rapid heartbeat for some } \\
\text { time, restlessness }\end{array}$ \\
\cline { 2 - 3 } $\mathbf{P}$ & 2000 & $\begin{array}{l}\text { Tremor, sleep, increased heart rate for some } \\
\text { time, restlessness, winding effect }\end{array}$ \\
\hline P: ethanolic extract of the whole plant. &
\end{tabular}

\section{DISCUSSION}

The P extract $(10.77 \%)$ has a low yield compared to that of $\mathrm{T}$. glaucescens $(14.8 \mathrm{~g})$ obtained from $100 \mathrm{~g}$ of organ (Konan et al., 2016).

For the cytotoxicity assessment, the decrease in the number of cells in the control tubes could be due to the lack of growth nutrients in the culture medium. The ethanolic extract tested showed a toxicity against the Vero $\mathrm{E}_{6}$ cell line on the second day. Indeed, this led to the death of more than $70 \%$ of cells at 10 $\mu \mathrm{g} / \mathrm{mL}$. According to the work of Coulerie (2012), the extracts causing cell mortality greater than $30 \%$ at a concentration of 10 $\mu \mathrm{g} / \mathrm{mL}$ are considered to be cytotoxic. Extract $\mathrm{P}$, having a low viability percentage, highlights a good cytotoxic effect (Konan et al., 2016). The sensitivity test conforms to the results obtained during the cell viability test. In fact, the concentration of $10 \mu \mathrm{g} / \mathrm{mL}$ caused the lysis of the cells in the wells 24 hours later and was accentuated 48 hours later. In addition, the concentrations $5 \mu \mathrm{g} / \mathrm{mL}$ and $2.5 \mu \mathrm{g} / \mathrm{mL}$ were also the cells.

The signs of toxicity observed 30 minutes after the animals were stored disappeared 1 hour after the administration of the ethanolic extract $\mathrm{P}$ before the animals had access to food. Regarding the acute oral toxicity of the plant, no death of mice was obtained. For this, the LD50 value would be greater than the quantity administered (Gome et al., 2011). According to the OECD classification in 2001b, LD50 would be greater than $5000 \mathrm{mg} / \mathrm{kg}$ of $\mathrm{BW}$, deducing that the ethanolic extract would belong to category 5 of toxicity.

\section{Conclusion}

The ethanolic extract $\mathrm{P}$ has cytotoxic potential at a concentration of $2.5 \mu \mathrm{g} / \mathrm{mL}$ to 10 $\mu \mathrm{g} / \mathrm{mL}$ on Vero $E_{6}$ cells. It also causes signs of toxicity at 300 and $2000 \mathrm{mg} / \mathrm{Kg}$ of BW. The LD50 being greater than $5000 \mathrm{mg} / \mathrm{Kg}$ of BW, the extract could be recommended as a 
mouthwash at a concentration of less than 2.5 $\mu \mathrm{g} / \mathrm{mL}$.

\section{COMPETING INTERESTS}

The authors declare they have no competing interests.

\section{AUTHORS' CONTRIBUTIONS}

The authors have all contributed in one way or another to the making of this work. Thus MRA-A, ABK, JAM-B and Y-AB carried out the chemical tests. Cytotoxicity was performed by MRA-A and EVA. As for acute toxicity, it was carried out by MRA-A and EK. Improvement and final manuscript approval was carried out by ANK-G, JAM-B and Y-AB.

\section{ACKKNOWLEGEMENTS}

The authors' thanks go to the BioOrganic and Natural Substances Laboratory, Nangui Abrogoua University, Abidjan, Côte d'Ivoire, the Department of Epidemic Viruses and the Animal Resources Management Unit, Institut Pasteur de Côte d 'Ivoire, Abidjan, Ivory Coast for carrying out the research work.

\section{REFERENCES}

Ambe ASA, Camara D, Ouattara D, Yapo CY, Soumahoro A, Zirihi GN, N'guessan KE. 2016. Etude ethnobotanique, évaluation in vitro de l'activité antifongique et cytotoxique des extraits de Enantia polycarpa (DC) Engl. et Diels (Annonaceae). International Journal of Biological and Chemical Sciences, 10 (1): 23-34.

DOI: http://dx.doi.org/10.4314/ijbcs.v10i1.3

Atsain MR Epse Allangba. 2017. Investigations phytochimique, microbiologique et antioxydante d'extraits d'organes de schrankia leptocarpa D.C (Mimosaceae). Thèse de doctorat, Université Nanguy Abrogoua, Abidjan, Côte d'Ivoire, p 150.

Allangba AMR, Kadja AB, Guessennd NK, Kouadio NJ, Mamyrbékova-Békro JA, and Békro Y-A. 2016. Etude phytochimique bio-guidée, activités antibactérienne et analgésique de décoctions éthanoliques d'une
Mimosaceae de Côte d'Ivoire. International Journal of Innovation and Applied Studies, 18 (2): 569-577. http://www.ijias.issr-journals.org.

Bayeli GI, Joiris V, Lohandjola GN et Habari JP. 2019. Contribution à l'étude des plantes médicinales utilisées dans le traitement des abcès dans le territoire de Bikoro, province de l'Equateur en RDC. International Journal of Biological and Chemical Sciences, 13 (1): 353-368. DOI: https://dx.doi.org/10.4314/ijbcs.v13i1.28

Coulerie MP. 2012. Etude phytochimique et pharmacologique de plantes de NouvelleCalédonie à potentialités anti-dengue. Thèse de doctorat, Université de la Nouvelle- Calédonie, France, p 290.

Fourasté I. 2000. Rappel de la toxicité de quelques plantes. Revue Française de Laboratoire, 323: 51-55. DOI : https://doi.org/10.1016/S03389898(00)80268-1

Galmiche F. 2011. le role de l'alimentation dans la sante bucco-dentaire. Thèse de Doctorat, N³690, Université de Lorraine, Nancy, p 180.

Gome MB, Kouakou K, Toure A, Traore F. 2011. Étude de la toxicité aiguë et subchronique de l'extrait aqueux de Passiflora foetida Linn. (Passifloraceae) chez les rats et les souris. International Journal of Biological and Chemical Sciences, 5(5): 1777-1789. DOI: http://dx.doi.org/10.4314/ijbcs.v5i5.1

Guessennd-Kouadio N, Boua BB, Dally IL, Atsain MR, Coulibaly K, Oussou KR, Kouamé BA, Kablan BJ, Békro YA. 2013. Screening phytochimique et activité antibactérienne de l'extrait éthanolique de la bourre de Cocos nucifera (Arecaceae), utilisé dans le traitement de la carie dentaire. European Journal of Scientific Research, 109 (3): 449-455.

http://www.europeanjournalofscientificre search.com

Irie-N'guessan AG, Kablan BJ, KouakouSiransy NG, Leblais V, Champy P. 2011. Evaluation de la toxicité de cinq plantes antiasthmatiques de la médecine 
traditionnelle ivoirienne. International Journal of Biological and Chemical Sciences, $\quad \mathbf{5}(3)$ : $\quad 1316-1319$. DOI: $10.4314 /$ ijbcs.v5i3.72285

Konan KF, Guessennd N, Koffi KE, Adjogoua E, Allangba-Atsain MR, Kouakou KL, Koffi KL, Dosso M. 2016. Terminalia glaucescens Planch. Ex Benth. (Combretaceae), a Medicinal Plant of Côte d'Ivoire Pharmacopoeia: Antibacterial Activity on Staphylococcus and Pseudomonas, Acute Toxicity on Mice and Lethal Effect on Vero $E_{6}$ Cells. International Journal of Pharmacy and Pharmaceutical Research Human, 7 (3): 290-303. www.ijppr.humanjournals.com.

Musa M, Nasir NFM, Thirumulu KP. 2014. Evaluation of royal jelly as an alternative to fetal bovine serum in cell culture using cell proliferation assays and live cell imaging. African Journal of Traditional, Complementary, and Alternative Medicines, 11 (1): 148$155 . \quad$ DOI : http://dx.doi.org/10.4314/ajtcam.v11i1. 23.
OCDE. 2001a. Sous-comité d'expert du système général harmonisé de classification et d'étiquetage des produits cliniques: danger pour la santé et l'environement-toxicité aiguë. UN/SCEGHS/2/INF.11, p 13.

OCDE. 2001b. Ligne directrice de l'OCDE pour les essais de produits chimiques, toxicité orale aiguë-méthode par classe de toxicité aiguë 423. p 14.

OMS. 2001. Forum africain sur le rôle de la médecine traditionnelle dans les systèmes de santé : Harare, du 15 au 18 Février 2000. AFR/TRM/01.1., p 53.

OMS. 2012. Santé bucco-dentaire. Aidemémoire 813, p 4.

Taylor RSL, Doudoroff M, Adelberg ED. 1996. Antivirial activities of Nepalese medicinal plants. Journal of Ethnopharmacology, 52: 157-163. DOI: 10.1016/0378-8741(96)01409-2

Vidal L. 2019. Pathologie dentaire et hygiène buccale à l'officine : Rôle du pharmacien, conseil et médication. Thèse de doctorat, Université Clermont Auvergne, Auvergne, p 129. 